\title{
Saudi Learner Perceptions and Attitudes towards the Use of Blogs in Teaching English Writing Course for EFL Majors at Qassim University
}

\author{
Fahad Hamad Aljumah \\ English Language and Translation Department \\ College of Arabic and Social Studies, Qassim University \\ PO box 478, Buraidah 51411, Saudi Arabia \\ Tel: 96-655-737-8030 E-mail: fahad.aljumah@gmail.com
}

Received: July 25, 2011

Accepted: August 30, 2011

Published: January 1, 2012

doi:10.5539/elt.v5n1p100

URL: http://dx.doi.org/10.5539/elt.v5n1p100

\begin{abstract}
Blog is one of the recent innovations that help students in finding opportunities to practice English writing outside the classroom. More educators have applied this easy-to-use technology to classroom instruction and language learning (Campbell, 2003; Johnson, 2004). The objectives of the study are (1) to investigate students' attitudes toward the use of blog in learning writing, and (2) to demonstrate the advantages and disadvantages of using blog in language learning. A total of 35 Saudi students majoring in English participated in this study. Data are collected from learners through questionnaires conducted at the end of the writing course (ENG143) during spring semester 2009. Responses indicate that students have a favorable perception towards weblog use in their writing classroom. Findings suggest that learner-perceived benefits of using blogs included increased interest and motivation to use English because of interaction with, and feedback from classmates and teachers.
\end{abstract}

Keywords: Blogs, EFL academic writing

\section{Introduction}

Writing is one of the most important language skills. It is a critical skill for students in school, college, and lifelong (Warschauer, 2010). Writing is also important for the instruction of foreign and second language learners for three reasons. First, writing well is a vital skill for academic or occupational success (National Commission on Writing, 2004), but one that is especially difficult for foreign and second language learners to master. Second, writing can be an effective tool for the development of academic language proficiency as learners more readily explore advanced lexical or syntactic expression in their written work (e.g., Warschauer, 2010). Third, writing across the curriculum can be invaluable for mastering diverse subject matter, as written expression allows learners to raise their awareness of knowledge gaps, abstract problem-specific knowledge into schemas that can be applied to other relevant cases, and elaborate mental representations of knowledge that can be more easily retrieved, while simultaneously allowing teachers to better understand the students' state of knowledge and thinking process and thus adjust instruction as necessary (Yih and Nah, 2009).

Although writing is one of the important language skills, many students consider it as the most difficult skill (Trang, 2009). This goes in line with Ackerman (2006) who reports that up to 40 percent of students in high schools are not doing well in writing classes. Ackerman adds that many students consider writing a chore that they do within the walls of the classroom. Similarly, Witte (2007) stated that students showed little interest in classroom writing activities and assignments. Many studies have also shown that it can be difficult to motivate language learners when it comes to writing (Kajder and Bull, 2003; Davis, 1997). Moreover, the students are not motivated to write with the audience in mind because a single teacher is the audience for most assignments. Furthermore, according to Mat Daud, Mat Daud and Abu Kassim (2005) and Yih and Nah (2009), the students' writing performance is related to anxiety as a result of their lack of writing skills. This may be due to students being generally passive learners who consider that their role is to absorb knowledge as it is presented to them in the traditional classroom.

As a consequence, this general agreement on the importance of writing skill and the poor performance of students in writing has provided the challenge for educators and researchers to look for ways to teach and motivate students to write effectively. Educators should attempt to find ways that don't cause a writer' block, and feel a responsibility towards their learners to create and maintain environments that motivate learners to continue learning even after 
class ends. However, this can be done through the use of recent innovations such as weblogs which are defined simply as "online diaries, logs of thoughts, reflections; a space for individuals to write whatever they choose with an option for readers to comment on what they have read" (Eastment, 2005). A web log encourages students to read, write, and converse more often. Web logs offer opportunities for authentic expression in the external world (Kajder \& Bull, 2003). Weblogs can motivate students to write and get them to understand that there is an audience for them, and that their communication through words needs to be effective because their peers and the world are reading. Blogs can remedy student disengagement with academic writing.

Other studies have also shown that blogs motivate many students to write well in the target language (Rodzvilla, 2002; Stiler \& Philleo, 2003; Liaw, Chen, and Huang, 2008). Through blogs, one can write and also comment on what one writes in expectation of a little discussion and a quest for common interests and individual differences. By responding on blogs, students can get feedback from other audiences throughout cyberspace. Students have an opportunity to read things in which they are interested and write things they truly wish to write, thereby determining their own texts in language education and combining text with conversations in a very personal and stimulating way. Many researchers, such as Downess (2004) and Hall and Davison (2007), have claimed that students' writing skills improve when they blog. Another study conducted by Kavaliauskienè and Vaičiūnienè (2006) indicated that the experience of writing on blogs (for an audience) provides opportunities to help students improve their knowledge of English. Nadzrah (2007) found that blogs let students compose writing with specific purposes that can encourage them to enhance their writing in the language constructively. Abu Bakar, Latif \& Ya'acob (2010) also indicate that through blogging, students are able to express and share thoughts, ideas and information with the wider public. Blogs are user-friendly websites which are easy to maintain and frequently updated by their owners.

Furthermore, blog provides a safer and more relaxed environment for language learners, especially for the shy or less confident ones (Hanson-Smith, 2001). Blog also enables individuals to express their thoughts at their own pace and in their own space so that, in contrast to traditional classroom settings, blog learners do not have to compete with their classmates for the instructor's attention (Bloch, 2004).

Blogs expand the opportunities for student interaction and the horizons of that "learning space" (Williams \& Jacobs, 2004, p. 232; Blackstone, Spiri and Naganuma; 2008) exponentially, and provide student writers with a far greater audience both within and outside the classroom. To illustrate, Pinkman (2005) writes that blogging becomes communicative and interactive when participants assume multiple roles in the writing process, as writers who write and post, as readers/reviewers who respond to other writers' posts, and as writer-readers who, returning to their own posts, react to criticism of their own posts. Dieu (2004) reaffirms this by stating that blogging gives a learner the chance to "maximize focused exposure to language in new situations, peer collaboration, and contact with experts" (p. 26).

To summarize, given the fact that blogging exposes students to a wider audience for their writing, we can hypothesize that students might attend more carefully to online writing opportunities (as opposed to papers submitted to an instructor). In the case of the writing prompts that ask students to read and reflect upon specific texts, it might be expected that students will read these texts more carefully when they know their interpretations will be online and therefore accountable to a larger audience.

\subsection{Statement of the Problem}

Although there are already existing studies and reviews on the use of blogs as an educational tool (Abu Bakar, Latif \& Ya'acob, 2010; Nadzrah Abu Bakar, 2009; Nadzrah Abu Bakar \& Kemboja Ismail, 2009; Seitzinger, 2006; Pinkman, 2005; Zhang, 2009; Sun, 2009; Song and Chan, 2008), further studies still need to be done especially with respect to the use of blogs in the second or foreign language learning classroom. This is because as a computer-based resource, the use of blogs as a teaching and learning tool is relatively new and it has only of late been gaining popularity (Pinkman, 2005). However, the popularity of weblogs in EFL classes in many parts of the world was one of the reasons that urged the researcher to adopt the blog as an innovative tool in teaching EFL writing to Saudi students at Qassim University, Saudi Arabia. Another reason for conducting this study was the rareness of studies that deal with the use of weblogs in the second or foreign language classrooms in many parts of the world. Studies on the use of blogs in the second or foreign language classrooms are still lacking especially the ones which involved EFL low proficiency learners. This has been confirmed by Pinkman, 2005; Zhang, 2009; Sun, 2009; Ward, 2004; Bloch, 2007 who point out that research focusing on blog use in English language classes is still relatively scarce in the literature. Furthermore, for ESL/EFL teachers, blogging would seem a potentially useful tool for creating a space to discuss issues that may not be the focus of the traditional classroom. I hope that this research study can contribute to the existing literature on blogs and EFL teaching and learning. 


\subsection{Research Questions}

All these previously discussed reasons urged the researcher to conduct a study and investigate how blogs help students in learning English, and their attitudes toward using it. More specifically, the present study seeks to answer the following questions:

(1) What are students' attitudes toward the use of blog in learning writing?

(2) What are the advantages and disadvantages of using blogs in language teaching and learning?

\section{Literature Review}

\subsection{Defining a Weblog: Forms and Features}

The weblog is commonly known as a blog. The term "blog" is a contraction of two words: web and log. Weblog, or blog for short, is used as both a noun and a verb. Blogs are a fairly new tool for written communication and interaction and appear in many different languages (Galien and Bowcher, 2010). The rise in popularity has resulted in new words being added to the English language, such as: blog, blogging, bloggers, and blogosphere (Ross, 2002).

Weblogs are defined simply as "online diaries; logs of thoughts, reflections; a space for individuals to write whatever they choose with an option for readers to comment on what they have read" (Eastment, 2005).

Similarly, Efimova and Fiedler (2003) characterize blogs as "personal diary-like-format websites enabled by easy to use tools and open for everyone to read" (p. 490).

A weblog (or blog) is a web-based space for writing where all the writing and editing of information is managed through a web browser and is immediately and publicly available on the Internet (Zhang, 2009).

\subsection{Types of Blogs}

Three types of blogs have been described by Campbell (2003): the tutor blog; the learner blog; and the class blog. The tutor blog is run by the tutor for the learner, and its purpose is to give reading practice to the learners, promote exploration of English websites, encourage online exchange by use of comment buttons, provide class or syllabus information, and serve as a resource of links for self-study. Learner blogs are run by individual learners themselves. Learner blogs are best suited for reading and writing classes. The class blog is the result of the collaborative effort of an entire class. It can be used for posting messages, images, and links related to classroom discussion topics. Class blogs could also be used as a virtual space for an international classroom language exchange (Campbell, 2003).

\subsection{Weblogs and Writing Instruction in ELT}

Computers have been used in writing classrooms for a long time. Originally the use of computers in the teaching of writing has been restricted to word processing. It is easy for teachers to make corrections and for students to make revisions. Later, some editing programs provided additional functions such as spelling checkers, and readability scores that helped students with textual errors. However, the use of computers in composition teaching has grown dramatically as new software programs and teacher-designed computer exercises are created. The programs and exercises that prompt the student writers to compose, revise, and offer suggestions for improvement have now become available.

In a short blog posting titled "Do weblogs improve writing?" Bernstein (2004) advocated "Frequent writing improves writing", "Writing for an audience improves writing", "Writing that matters improves writing", and "Writing on a computer improves writing". However, to EFL learners, frequent writing may not necessarily improve writing. Nevertheless, it will definitely be helpful if students do not only write frequently but also look up English dictionaries or use Internet to help them express their ideas clearly and correctly. EFL learners' writings will be more or less influenced by their first language. The improvement of writing will be questioned if EFL students write English frequently but present their thoughts with the style of their first language. And some students answer that they will look up an English dictionary or ask someone else when they don't know how to express their ideas in English. To an EFL learner, it is a critical step to become a successful writer if whenever he is aware that something wrong with his writing, he can effectively find an answer from an English dictionary or Internet.

Campbell (2003) researched learner attitudes to weblogs by administering an anonymous survey to 57 learners in four classes. His results can be summarized as follows: the large majority (86\%) feel that the blog is 'OK' or 'good', most students only rarely or occasionally read the entries, preferring instead to go straight to the class websites for homework or presentation information. Learners seem to prefer to do only what is required of them. This assumption is reinforced by decreasing numbers of learners following links in the entries and making comments. The majority (95\%) rarely or never utilize the EFL learning resources available for self-study via permanent links in 
the margins of a weblog. Although most learners recognized the value of a blog, they claimed that they didn't have the time to take advantage of it.

Teaching writing and reading English for Specific Purposes through weblogs was studied by Arani (2005), who maintains that approximately three quarters of the class of forty students preferred writing the weblog to the more traditional written journal; most students believed that the weblog can improve English; seven disagreed; 15 students said that they would definitely continue using the weblog; 15 said they definitely would not, and 10 were unsure.

Simsek (2009) investigates the effect of weblog integrated writing instruction on students writing performance. Also students perceptions toward weblog used in their writing courses has been examined Seventy undergraduate students in the Department of Primary Education at Marmara University participated in this study. Data were collected through students, written products and weblog perception questionnaires. The finding indicated that weblog integrated writing instruction improved the writing performance of students. Moreover students had a favorable perception towards weblog use.

Ellison and $\mathrm{Wu}$ (2008) in their exploratory study explore student perceptions of blogging in the classroom regarding (a) which specific characteristics of educational blogging (writing an entry, reading other students' blogs, or reading other students' comments on one's blog) are most helpful for understanding course content and (b) other aspects of the instructional blogging experience, such as the process of providing and receiving peer feedback. Quantitative data analysis revealed that reading other students' blogs was believed to be most helpful for understanding course concepts. Analysis of the open-ended responses revealed a need for more guidance regarding the process of reviewing and critiquing the work of peers and appreciation for the way in which blogging exposed students to more diverse viewpoints from their peers. Pragmatic guidelines for instructors wishing to incorporate blogging into their classroom activities are discussed.

Pinkman in his study (2005) seeks to determine the usefulness of using blogs in the foreign language classroom, and to assist foreign language professionals interested in developing learner independence in their own learners by using this relatively new computer-based learning forum. Findings suggest that learner-perceived benefits of using blogs included increased interest and motivation to use English because of interaction with, and feedback from, classmates and teachers. There is also indication, however, that although the project helped to improve reading and writing skills, some learners were more interested in developing oral communication skills not directly addressed in the blog project. The findings also suggest that learners who participated in the blog project were interested in continuing to blog even after the semester finished. Further research needs to focus on whether or not learners did indeed continue using this resource after the course ended, and in which foreign language courses this project is most suitable.

\section{Research Methods}

This study was implemented in English Department at Qassim University (QU) in Saudi Arabia. The class was an English writing course (ENG143) and was made up of 35 learners. In a computer lab, learners were shown a sample blog created by the instructor. Learners were then instructed on how to design their own blog on Blogger.com, a popular and easy-to-use free blog provider. Once the learners had completed their blog they were instructed to write their first blog entry, a self-introduction. A list of blog addresses was collected by the instructor and posted on the instructor's main blog. Learners were then instructed to read two to three of their classmates' blogs and comment on them. After the initial lab session, the project was conducted as an out-of-class project. Learners were responsible for writing one entry of 150 words per week, and commenting on two or three of their classmates' blogs. The contents of their entries were to be based on classroom context. For example, if learners studied how to express their opinions about pollution that week in class, they were encouraged to recycle or reuse those skills on their blog.

After the semester was completed, the questionnaire was completed, and open-ended questions were asked of the students to gauge their attitudes on the project.

\subsection{Setting up a Blog Site}

The researcher used a free blogging website (blogger.com) to explain how to create a blog. Students were also given a video manual on how to create a blog. The process of creating a blog is a fairly simple, three step process as explained by the Blogger.com website: 1) create an account; 2) name the blog; and 3) choose a template. Once the blog is created, the students can add as many postings as they like. All postings are listed chronologically in the blog. Readers can freely view the contents of the blog and post comments. The owner of the blog can visit the comments left for their blog postings and the communication continues. This way, an asynchronous interaction can take place (see Figure 1). 


\subsection{Blogging and Academic Writing}

The English Writing Course (ENG143) is a compulsory course to be taken by the undergraduates in the Faculty of Arabic and Social Studies, Qassim University, KSA. The course runs for three hours per week over a period of 14 weeks in a semester. Its main objective is to equip the undergraduates with the writing skills which will enable them to cope with the academic demands while at the university. During the first week of the term, a tutor blog was opened at Blogger. The tutor blog posts included a general welcome message, instructions on how to write comments to the entries and a slideshow about the content of the writing course.

Instructors frequently mentioned topics in the blog posts and motivated students who had read the posts or done the activities to share their experiences with the class. Based on these uses, four specific goals for the use of the class blog were created:

1. To write using a variety of genres both personal and academic

2. To discuss and negotiate a variety of issues related to academic writing

3. To provide a space outside the classroom for students to collaborate and argue

4. To create texts that could both express students' own viewpoints and be used by other students to critique or support their views

By framing the use of blogs in this way, we hoped to capture different types of writing, which could be used to achieve the goals of the course.

Although the course was structured around the rhetorical functions of definition, description, comparison and contrast and classification, some of the topics in the posts were intended to make students become aware of their learning strategies in general, their EFL writing strategies in particular, how they used dictionaries and how to go about learning vocabulary. Other topics were about how to write comments in the blog. Students were asked to visit two other students' blogs and then post a comment. In this way, each student added blog postings and comments on other students' blogs. The questionnaire was given to students in the final week of the class.

\subsection{Participants}

The participants in this research were 35 undergraduate students in The Department of English Language at Qassim University, Saudi Arabia. Total number of respondents was 35 males aged 19 to 21. The period of research on application of blogging in the writing course lasted one term, fall 2009. The employed methods of gathering data consisted of administering specially designed questionnaires, analyzing students' responses, carrying out blogging activities, providing feedback to learners, evaluating learners' performance in various online activities, and analyzing the utility of blogging.

\subsection{Instrument of the Study}

A survey questionnaire was designed for the purpose of this study and it was pilot-tested on a group of students to check its validity and reliability. Improvement on the piloted questionnaire items were then made based on the students' feedback. The questionnaire items extracted from instruments used in previous studies under the condition that repetition was avoided (i.e. Campbell, 2003; Pinkman, 2005; Eastment, 2005 and Walker (2005). The investigator necessarily modified and added items to make the questionnaire relevant and appropriate for the Saudi students learning English as a foreign language. The final version of the questionnaire had three major parts. The first part consists of eight items. It included basic information about the participants, such as experiences in using the Internet. In the second part, forty six questions were designed to elicit participants' attitudes toward the use of blogs in learning writing. The last part contained two open discussion questions for participants to give their opinions about the advantages and disadvantages of using blogs in learning English, and the difficulties and benefits students encountered in using a blog. The questions in the questionnaire were quantified by a Likert-scale of 1 to 2 $(1=$ Disagree, 2 = agree). The reliability of the second part was determined using Cronbach's alpha (.90). The questionnaire reached a high reliability.

The questionnaire was administered during class in the last week of the semester (the students would have already completed the writing course) to get their feedback on the effectiveness of the project in developing their English writing skills, the advantages and disadvantages they might have faced when doing the project, as well as their suggestions to improve the project. With their consent, a random number of students were invited to take part in questionnaire so that the teacher could get more in-depth information on their use of blogs. The responses were analyzed using descriptive statistics in the form of frequency analysis and percentages and the results were then tabulated. 


\subsection{Statistical Analysis}

The data were computer-analyzed using an SPSS, 10.0 Program (Statistical Package for the Social Sciences) for Windows and Microsoft Excel, version 2000. A reliability test was used to verify the reliability of the questionnaire. Students responded to the questionnaire. Closed and open-ended questions solicited students' perceptions on using the blog as a learning tool. A 2-point Likert-type scale was employed with 1 to 2 representing for "Disagree", and "Agree". Key results and findings will be addressed according to the several sections of the questionnaire.

First section includes demographic and previous blogging experience. Second section deals with students attitudes towards the use of blog. Third section deals with the advantages and limitations in using the blog.

\section{Results and Discussion}

Thirty five undergraduate students in The Department of English department at Qassim University participated in this study. 35 students (100\%) responded to the questionnaire. Closed and open-ended questions were used. A 2-point Likert-type scale was employed with 1 to 2representing for "Disagree", and "Agree", Key results and findings will be addressed according to the several sections of the questionnaire. First section includes demographic and previous blogging experience. Second section's focus was on students' general perceptions in using the blog as a reflective and communication tool. Table 1 summaries the results. Students were also asked to list down the advantages and limitations in using the group blog. Quantitative data via open-ended questions were also collected after each section. Additional open-ended questions were also asked to gain more insights from the students. The questions and responses to the questionnaire are shown in Table 1,2 and 3.

The first Part of the questionnaire includes basic information about the participants.

1. Before the writing course began, I had previous experience in (check as many as necessary):
A. the WWW (i.e. Internet Explorer, Netscape, Mozilla Firefox)
B. email
C. chats
D. social networks (i.e. Facebook)
E. Blogs

2. My previous use of the web was mostly in:
A. Arabic
B. English
C. Both Arabic and English

3. Had you heard about blog or had your own blog before this course?
A. Yes, I had heard about it, but I had no idea what it was.
B. Yes, I had heard about it and also had a rough idea what it was.
C. No, I hadn't heard about it.
D. Yes, I had had my own blog.

4. Have you ever blogged before using the tutor blog?

5. Do you have your blog? No Yes

6. How often do you visit the tutor blog?
A. always,
B. frequently,
C. sometimes,
D. rarely

7. How many hours do you spend on the Internet ?
A. more than 20 hours a week
B. 11-15 hours a week
C. 6-10 hours a week
D. 1-5 hours a week

8. I am usually online

A. from my computer at home 
B. at a friend's or relatives' house

C. at the university (teacher's office)

D. at a cyber café

\subsection{Visibility of Blogs in Saudi Arabia}

Regarding the survey for the writing course, after thirty-five students completed it, the results showed that before the course, most students (88\%) had had experience with the Internet: $86 \%$ had experience with emails, $76 \%$ with chats, $72 \%$ with social networks, but only $5 \%$ had had experience with blogs. This finding was consistent with the results of the previous surveys by Perseus (2005) who indicated that only $5 \%$ of over 30 year olds were weblog active. When asked to comment on the kind of language they use when browsing the internet, many students (62\%) responded that they browsed the web in both languages while 34\% did it in Arabic and very few (24\%) used English to browse the web although most of them reported it would depend on the task.

When asked to comment on how they had heard about blog or had their own blog before this course, Quiet a number (71.42\%) of respondents hadn't heard about what a blog was before I asked them to create one; $4(11.43 \%)$ had heard about it, but had no idea what it was; $3(8.57 \%)$ had heard about it and also had a rough idea what it was. Only $3(8.57 \%)$ respondents had their own blog. This indicates that blogs are not well-known around the young generation in Saudi Arabia.

As to the tutor blog, all students visited it with different degrees of frequency: some (13.6\%) always checked it; half of them checked it many times and $22.7 \%$ sometimes. In the case of comments, although a few (4.8\%) wrote them always, $33.3 \%$ wrote them many times and $42.9 \%$ sometimes. This finding is similar to that reached by De Izquierdo and Reyes (2009).

Concerning the time spent online, $26 \%$ of our students reported they spent more than 20 hours per week, $16 \%$ between 11-15 hours, and 24\% 6-10. A percentage of 22\% reported they spent only 1-5 hours online weekly. These results may be due to the kind of access they have to the Internet. Notice that $68 \%$ of our students have Internet access from home while another $18 \%$ get logged in at the university, cybercafés, friends or relatives.

The third question of this study was to report on the attitudes of the students $(\mathrm{N}=35)$ towards the blog which was constructed in their learning environment at Qassim University, Saudi Arabia. The discussion will highlight the most significant findings in the second part of the questionnaire.

\subsection{Students' Responses toward the Use of Blog in Learning Writing}

Analyses of qualitative data indicated that majority of the students (see Table 1) showed a positive attitude towards using blogs in their learning activities. 34 out of 35 of the students were glad that they had their own English blog. As for item (2), 91.4\% (32) of students said that it was easy to create and publish their blogs, while only $8.6 \%$ said it was hard for them to create a blog, but almost all managed to complete their task and found that they $(85.7 \%)$ have no difficulty using their blog (item \# 3), and they (82.9\%) feel comfortable using their blog (item_\# 4). This finding goes in accordance with that of Song and Chan (2008) and Galien and Bowcher (2010) who point out that the majority of the students found it easy to use the blog in the assignment. Most of the students also mentioned that it is convenient as they can access the blog at their own pace. They appreciated the fact that they can do it anytime, anywhere. Writing on blogs $(91 \%$; 37) was interesting and enjoyable (item_\# 5). This finding is consistent with that of Song and Chan (2008) who said that the students in their study enjoyed using the group blogs as a mode of learning. Song and Chan added that Students' feedback also revealed that they see the group blog as a new, fun and interesting way to learn.

A high percentage of students (80\%) also think that the learner blog is not a waste of time (item \# 6). These findings were Similar to the findings of previous studies (e.g., Williams \& Jacobs, 2004, Abubakar, Latif \& Ya'Acob: 2010) which indicate that most students were able to set up and publish their blogs without facing any significant difficulty related to technical issues. The majority of students think it is simple to use blogs and feel comfortable using the blog. The students in Tekinarslan study (2008) also felt comfortable using the blog and enjoyed writing on weblog.

When asked if it is fast and convenient to update information on the blogs (item \# 7), 31 out of 35 students responded positively (see Table 1). This finding goes in accordance with the results of Song and Chan, 2008 who point out that the blog is updated instantly and allows readers to post comments. Moreover, they state that the students in their surveys express their joy and happiness by easily updating posts to blogs.

More than three quarters of the students $(71.4 \%)$ "I like posting many articles and photos or clips of films on the blog (item \# 8)". This finding has been reached by Blackstone, Spiri and Naganuma (2008) who showed that about the same percentage (78\%) stated that they liked posting classroom assignments on their blogs. The same finding 
has been confirmed by Song and Chan, 2008 who mentioned that Students developed visual literacy skills as they transformed their essays into online presentations.

In general, students expressed general approval of the blogging medium, citing the added convenience and the uniqueness of the medium, although students also mentioned technical concerns, such as experiencing anxiety about whether the assignment had been received.,

The students' reactions to comments on their blogs from their instructor and peers: The students' reaction to comments on their blogs from their peers was one of the most important findings that have been reached in this study

As shown in Table 2, on item \# 9, "I like to invite my friends or classmates to read my blogs", 27 out of 35 students (77.14\%) expressed positively. This finding is in line with that of Bakar and Ismail (2008) who indicate that most of the students invited their friends to read their blogs.

When asked if "reading the comments and entries of my peers on the blog helped me to learn and improve my own writing (item 10\#)", 74.3\% of students expressed their positive agreement. With respect to item 11\# "I like making comments on my classmates' posts", a large number of the students $(68.6 \%)$ were positive, whereas $31.4 \%$ felt uncomfortable criticizing others' work.

On item 12\#, many students $(80 \%)$ think that responding to the comments received on their blog improves their writing. This finding is similar to that reached by Ellison and Wu (2008) who point out that the students in his study revealed that responding to the comments of their peer gave constructive thoughts about how to improve my writing. They added that the students liked when they got feedback from their partners to learn what they needed to change and if they needed to write more for their paragraph.

On item 13\#, "I found it difficult to comment on the blogs of my peers",

$71.4 \%$ of students expressed their disagreement with this view. This finding differs from that reached by Ellison and $\mathrm{Wu}$ (2008) who indicated that students in their study expressed frustration with the shallow or shoddy quality of peers' entries, which made giving feedback difficult: "I found it difficult to comment on the blogs of my peers, as some of them appeared to only write 'rants' and not actual, reasoned responses?' In summary, students enjoyed commenting but were not convinced of the pedagogical benefits, and appeared to desire more guidance in regards to structuring their remarks to be helpful as opposed to "preachy" or overly negative.

When asked about how they felt about other learners commenting on their blog (item 14\#), 85.7\% of learners responded positively, saying that they "enjoyed" or "liked" reading comments from their classmates. This finding goes in accordance with the results of Pinkman (2005) who thinks that peer comment on the blogs helps students make progress in writing skills. Using peer review is beneficial for students to form critical thinking skills which are used to revise their writing. By doing so, students can learn other's viewpoints on it, knowing what comments they will get after they finish an essay. The online peer review, compared with oral comments in person, has the following advantages: time and place independent, no pressure to quick respond, and the competence to control conversations.

On item \# 15, "I don't have to worry of what my friends would think of my language when I blog in English". 80\% $(28 / 35)$ of students answered in agreement. This finding goes in accordance with that of Abu Bakar \& Ismail (2009) who point out that the majority of the students agreed that they were not worried what their friends thought of the language that they had used when blogging.

On item \# 16, for the statement “I like reading my classmates' written posts", high percentage of participants (91.4\%) expressed positively. Students enjoyed reading other student's blogs because they like to expand their way of thinking; everyone has a different perspective on things:' "People have opinions, and they can only write what they see, but they restrain themselves because they don't want to sound preachy or start any arguments. They also like having class mates make comments on their posts.

In item \# 17, "I feel uncomfortable about my peers' comments", $60 \%$ of the participants reject this statement. Only $40 \%$ of students agree with the views mentioned by Ellison and Wu 2008 in their study. They indicated that receiving and providing peer feedback (comments) made some students uncomfortable. Students felt uncomfortable criticizing others' work. Students may not have understood the difference between constructive criticism that focuses on the content of the work as opposed to attacks on character, as evidenced by concerns about appearing too aggressive or hurtful in their comments. Specifically, some students were uncomfortable commenting on others' work because they didn't want to tell other students they were "wrong". Ellison and Wu added that the unfiltered nature of the comments from peers were distressing to some, such as the student who said she disliked "the potential for negative feedback" or another who was disappointed by the lack of feedback: "Nobody posted a comment to 
mine: "Students expressed concern about commenting, both from the perspective of sender as well as receiver. Perhaps because little guidance in providing critical and appropriate feedback was provided by the instructor and many students had not previously experienced this kind of peer review, some students felt uncomfortable making comments that might be perceived as negative or insulting. In summary, students enjoyed commenting but were not convinced of the pedagogical benefits, and appeared to desire more guidance in regards to structuring their remarks to be helpful as opposed to "preachy" or overly negative.

When asked how they felt about their teacher comment on their blog (item 18\#,), all learners responded that they "enjoyed" the comments. In fact, since 100\% indicated that they appreciated their teacher's comments on blog posts, input from the teacher can still be considered vital within the context of these "blog dialogues". The comment function of the blog site enables teachers to give timely responses to a student's blog post. Unlike the usual homework submission, in which a teacher's corrective feedback can only be seen by one student, a comment on a blog post can be seen by different students.

On item $28 \#$, the majority of the students (85.7\%) feel that blog is a useful tool for them to share ideas with friends online. Sharing information and having access to other group members' opinions were some of the top reasons why they viewed the blog as an effective learning tool

\subsection{Blogging vs. Writing on Papers}

When comparing writing on blogs with writing on paper, in general, a high percentage of students $(71.4 \%)$ indicated that they prefer to practice their writing in the blog rather than in the class (On item \# 20). This concurred with the results of Arani (2005) who maintains that approximately three quarters of the class of students preferred blog writing to the more traditional written paper. This finding is similar to that reached by Song and Chan 2008 who highlighted a difference between blog writing assignments and the traditional classroom writing activities. The enthusiasm for blog writing was uncharacteristic.

Thirty of students $(85.7 \%)$ express that they could write better when blogging than on paper in the class (On item\#21). Moreover, $71.4 \%$ (25) of the students said they were more creative when blogging than on paper (On item \#22). This is because to the students could include video clips, pictures and sounds in their blogs. The purpose was not only to make the site more interesting, but also to make it more informative. This could not be done on paper. In addition to that more than three quarters of students $(74.3 \%)$ agree that they could get help when they wrote on the blog like in the class (On item \#23). The students (60\%;) also pointed out that they were able to build their self confidence in writing when blogging compared to writing on paper (On item\#25). This blogging project helped increase the students' motivation. This finding is supported by Blackstone et al. (2007), Fellner \& Apple (2006) and Pinkman (2005). A high percentage of students (91.4\%) felt that it's more motivating to post an entry on the blog than to submit an essay on paper (item 29). They added that it's also very fun, which makes learning more enjoyable. This provides further support to Fellner \& Apple's (2006) view that blog can be more motivating because a familiar task becomes fresh in the new medium of the Internet. Furthermore, $68.6 \%(27)$ of them said that they could write longer when writing online (On item \#28). When we observed their writing on the blogs, we saw that their writing became longer, and sentence structures became more complex. This finding is similar to that concluded by Abu Bakar, Latif \& Ya'acob (2010) who realized that they were able to write longer online compared to writing on paper. This is because the environment of blogging is different from that of writing on paper.

When asked about their participation in online writing compared to writing in the class $91.4 \%$ (On item\#30) of the students indicated that they were able to express themselves better in writing on their blog than in the class. This finding is consistent with the results of Cobanoglu (2006) who points out that the blog seems to be able to promote a sense of belonging for some of them and increased their self-confidence. It also creates an equal opportunity for them to express their opinion unlike in conventional face-to-face large classrooms. 27 of students $(77.1 \%)$ also add that they feel no pressure when writing on my blog because they have more time to write (24). They mention that the time for them to express themselves in writing was unlimited. They feel no pressure when writing on their blogs because they have more time to write and there was no pressure for them to finish the task (item\#24). They also feel free to write on the blog than in the class (item\#36).

When asked which way they like to submit their assignment, the majority of the students (91.4\%) prefer the blogging way of submitting their assignments to the traditional way of submitting assignments (item\# 29). This finding is similar to the results of who point out that Many times students had to print out the assignments, put them in a folder and go to campus in order to submit their assignment. This traditional way of submitting assignments is time consuming, expensive and requires too much work in comparison to electronic way of submitting assignments such as blogs and email.

When asked if they liked to write their opinion on the blog more than they can with the traditional classroom when 
they agree or disagree with peers' comments, about $91.4 \%$ of the students were either agreeing or strongly agreeing to the view that they were motivated to voice their opinion on the blog (item\#30). This is another significant finding because in most of the face to face lectures for this course, when students were asked to express their opinions, many were uncomfortable and unable to do so. Contrary to this finding, most of the students were found to be passive learners in the traditional classroom, quietly taking down notes and needed to be coaxed to ask questions or give an opinion.

\subsection{Students' Responses toward Blogging and Writing}

This section of the questionnaire examined the students' perceptions towards using blogs as a platform for writing in order to develop their writing skills in English (see Table 1). A high percentage of the students $(74.3 \%)$ responded positively to using the blog. They agreed that having their own the blog encourages them to write better (On item \#36). This finding goes in line with the results reached by Miranda Bella (2005) who concludes that weblogs can enhance students' writing skills and abilities. The students are aware that their written work is published online for the whole world to see, and this becomes an effective motivator. They realize that anyone can read their writing, especially their parents, other family, and friends. The presence of a real audience encourages them to produce high-quality work. The students also like the idea that their work will be published instantly. This is rewarding for them. They understand that all their hard work and effort is worth the end results.

When asked if their writing skills have been improved since they began blogging (On item\#31), the students (82.9\%) agreed to the view.

\subsection{Students' Responses toward Blogging and Learning Grammar and Vocabulary}

As illustrated by the data in Table 1, blogging appeared to have provided the students with the opportunity to learn grammar (item \#40) and develop vocabulary independently (item\#32). A considerable number of them $(80 \%)$ strongly agreed that they had learnt and improved their L2 grammar while 91.4\% of them perceived that they had acquired new vocabulary when reading their friends' blog postings (item\#34). Likewise, $83.2 \%$ of them generally agreed that their skill in guessing words meanings had improved through blogging (item\#41), and $77.1 \%$ thought that they were able to use different word forms in English (item\#33).

\subsection{Useful Tool for Writing}

All the students felt that using blogs in the class as a writing tool was a good idea (item 39). The students benefited a lot from this activity. They indicated that when using blogs they were able to write better because they $(60 \%)$ were more aware of the need to check their writing before posting (item42), and when writing on papers, some of them (27.1\%) did not carefully check their grammar (item41). Most probably, they realized that when writing online, the Web site is open for everyone to read, and they tried their best to write using correct grammar and sentence structure (Table 2).

(On item\#44) “When I write on the blog, I don’t worry about mistakes", most students (88.7\%) expressed agreement. This finding is similar to that have been reached by Cobanoglu (2006) who Said that the participant in his study don't worry about mistakes when they write on the blog.

On item \# 43, Twenty nine of the students $(82.6 \%)$ like to "write a draft of what they wanted to say before they submitted the blog response". High percentage of students checks the dictionary while they were writing their blog response (On item \#35). The majority of students still engaged in typical tasks associated with writing, such as drafting and checking the dictionary. This indicates that the students valued the task and wanted to post something that reflected their skill in writing

On item \#38, "Using web logs for writing can increase my productivity."

Almost two thirds of students (65.7\%) expressed their agreement. This finding is supported by Galien and Bowcher (2010) who state that there was significant improvement in the writing quality of each paragraph as students progressed through the editing process with the pre-service teachers. Editing is one of the most difficult steps in the writing process. This is true from both the writers' and the teacher's perspective. It is a challenge to conference with every student and to provide the time and attention he or she deserves. After all, there is only one teacher. At the same time, the more attention each student receives, the better the end result.

When asked if "they enjoy the blog project (item \#45)", the majority of the students (97.1\%) agreed with the view. This finding supported the results of Pinkman (2005) who highlighted that all of the learners interviewed responded that they enjoyed the blog project overall. When asked about the advantages of the project, reasons why they enjoyed using blogs in the classroom, and what they learned from the project, learners reported a variety of responses. Eight learners agreed that they enjoyed interacting with classmates and learning from them. Seven learners cited 
that they thought their writing skills had improved from participating in the project. Five learners responded that the project assisted them in learning and using new vocabulary.

\subsection{Intention to Continue Blogging}

Of the thirty - five learners participated, twenty-nine agreed that they would continue blogging (On item \#53). This finding is consistent with that of Abu Bakar, Latif \& Ya'acob (2010) and Pinkeman (2010) who indicated that most of the students wanted to continue blogging after they completed the course, and all of them suggested that writing on blogs should be a class requirement.

To sum up, the benefits of this project can be seen not only in developing the students' reading and writing skills, increasing their motivation, improving their background knowledge, helping them learn autonomously, building a community of learners, but also providing powerful feedback tools.

\subsection{The Advantages of Using Blogs in Learning English}

In the open discussion questions, two questions were included. They are: 54 . What do you think that the advantages of using blogs in language learning? And 55. What do you think that the disadvantages of using blogs in language learning? The participants were asked to list down any advantages and disadvantages that they found while using the blog in their English writing. The answers were synthesized into different categories. Table 2 shows the percentages and rankings. About $34.5 \%$ of the participants thought that the merit of blogs was to give participants an opportunity to practice writing. Another valuable advantage was free writing. Participants could write down whatever they wish. This finding affirms the results of Tseng's study (2008). A third advantage reported by a reasonable number (17 out of 35) is that the blog provides the avenue for students who are struggling or uncomfortable to voice their opinion in person. Students may be embarrassed and lack self-confidence to speak in class. Even though all the courses in the faculty are taught in English, all of the students are not native English speakers. This concurred with the findings of Cobanoglu (2006), affirming that blogs provides an alternative voice for students who were not native English speakers. This is also evident in some of their comments:

It's easy to voice out your opinions than speak it face to face. For people who are not good at speaking out their opinion in public, a blog offers them an opportunity to convey their thoughts without having to come in contact others face to face.

The fourth advantage was that blogs were helpful in learning new vocabulary. Fifteen learners responded that the project assisted them in learning and using new vocabulary. The same finding has been reached by Song and Chan (2008).

The easy use of blogs was the fifth advantage. 25 out of 35 learners write that blogs are very easy to use programs, there is nothing confusing in creating and editing a blog page. Also, students did not have to worry about where to publish their blog page, because it is published in two minutes without any charge after creating the blog page. They just needed to approve the publication. This is similar to the results of Song and Chan (2008) who indicated that one of the main advantages that the bulk of the students stated was the ease of use, accessibility and flexibility.

Advantage No.6 was convenience. Participants could maintain their blogs whenever they were in the mood or inspired. Many students (23 out of 35) thought that blogs were more convenient and effective tools for disseminating information than traditional methods such as using folders and printed copies. This traditional way of submitting assignments is time consuming, expensive and requires too much work in comparison to electronic way of submitting assignments such as blogs and email.

They could just go online at any time and write down their thoughts. This finding is consistent with that reached by Richardson (2006) who interviewed a group of students in his study.

\subsection{The Delimitations of Using Blogs in Learning English}

As in Table 3, when students were asked about what they thought the disadvantages of the blog project were, four learners responded that they found that the lack of feedbacks and corrections was one of main limitations. As participants practiced writing on their blogs, it was difficult for the teacher to make corrections one after another, especially for a large class. The amount of workload for the teacher was high. But the participant thought it was better for the teacher to give them feedbacks or made corrections of each post.

Another limitation reported by many students (19 out of 35) was that blogging activity was too time-consuming. Learners commented on that they found the project time-consuming or wished they could have had class time to complete the assignment. This finding is similar to that reached by Cobanoglu (2006) who indicate that time constraints is another disadvantage of blogging. It could be suggested that time constraint is an excuse not to engage in the blog experience rather than a reason despite similar findings in a study by Ding (2008). 
A third disadvantage was failing to log in and create a blog represents one of the difficulties that learners encounter in using blogs. Quite a number of participants (16 out of 35) thought their lack of technical experience was a big problem when they were creating their blogs.

The fourth limitation, as reported by fifteen students, is that some teacher blogs lack regular updating and fail to respond to learners' questions without delay, which affected learners' enthusiasm and initiative in ELT. The establishment of teacher group blogs might solve this problem through cooperative teaching. This finding supported the result of Ding (2008).

The fifth limitation mentioned by a considerable number of students (12 out of 35) was that they don't follow the traditional format of writing the paragraph or essay when blogging. This goes in accordance with the results of Tekinarslan (2008) who report that people do not care about the traditional format (like opening, developing, chafing and concluding--the four steps of classic writing); however, once forming the bad habit of it, people will forget how to write an essay on a piece of paper in good order.

The sixth ranking reported by a reasonable number of students (10 out of 35) was lack of participation and physical contact with students. This was one of the difficulties that impede the use of blogs in EL instruction. This finding is similar to that of Ho (2009) who cited that lack of continuous and spontaneous communication as another shortcoming of a blog project.

The seventh disadvantage for using weblogs was some negative comments. Ten students mentioned that delivery of negative comments was one of the main disadvantages for using blogs. While collaboration between an instructor and learners seemed to be important, students felt feedback from their classmates was not so useful to improve their language skills. At first, students did not know how to give feedback. Second, such comments as 'I like your entry' or 'Your entries are really useful' were not helpful. Third, few students responded to peer weblogs from grammatical and pragmatic viewpoints. In addition, it seemed to be difficult for students to comment on peer's weblogs if their entries didn't have anything interesting to share.

To sum up, the benefits of this project can be seen not only in developing the students' reading and writing skills, increasing their motivation, improving their background knowledge, helping them learn autonomously, building a community of learners, but also providing powerful feedback tools.

\section{Conclusion}

The use of the internet as a resource in language education is rapidly expanding, and opening up exciting avenues for developing foreign or second language skills (Song and Chan, 2008 and Galien and Bowcher, 2010). One of these avenues is the blog. A weblog is an innovation of the Internet. It is authentic, and it provides students with a real-world activity. However, the emergence of the Weblog as a recent innovation can serve as a valuable tool for the teaching of foreign language writing (Yih and Nah, 2009). However, the current study attempts to pursue the students' attitudes towards the use of blog in English language writing. Similar to Fellner \& Apple (2006) and Pinkman (2005) Ding, 2008; Galien and Bowcher, 2010, I found that blogging helped the students improve their writing skills. The data obtained from the study also proves that the students formed positive attitudes toward using blogs in English writing classes. The findings of the present study also prove that blogs can be popular in the language classrooms, especially for Saudi students who learn English as a foreign language. As demonstrated by the attitudinal survey data, the majority of students stated that they enjoyed posting, reading their classmates' posts and making comments on those posts, they almost unanimously stated that they liked having their classmates and the teacher write comments on their posts. Students feel more comfortable with blogs as they post messages. A large majority also found the blogging system useful, motivational and effective for improving their writing.

On the other hand, the study provided teachers with insights into the disadvantages (e.g. lack of feedbacks and correction, passive behavior, distraction, time-spent, and computer problems) of using blogs in language teaching. By solving these disadvantages, I hope to improve the efficiency of English teaching by using blogs and students will be more willing to write, and share their blogs with classmates and people all over the world.

\subsection{Limitations and Further Research}

No study is without limitations. This study is no exception. The first one is the small number of sample size. This study reports the results of student perceptions about blogs in only one class in Qassium University in the Kingdom of Saudi Arabia. Therefore, the results cannot be generalized. The numbers of participants could be increased and students from different majors, different English proficiency levels, or even different universities could be compared in future studies. Further study may be needed to detect the effectiveness of the blogs as learning and teaching tool. Moreover, Studies should be done concerning how best to motivate students to make use of the full learning 
potential of blogs as well as how to teach them the necessity of privacy, ethics, and appropriate content. Further study should also be done with an analysis of benefits and difficulties as seen from both student and teacher perspectives. Further research needs to focus on whether or not learners did indeed continue using this resource after the course ended, and in which foreign language courses this project is most suitable.

\section{References}

Abu Bakar, N., Latif, H., \& Ya'acob, A. (2010). ESL Students feedback on the use of blogs for language learning. $3 L$ The Southeast Asian Journal of English Language Studies, Vol. 16 (1)

Ackerman, J. D. (2006). Motivation For Writing Through Blogs. Master of Arts.

Arani, J. A. (2005). Teaching writing and reading English in ESP through a web-based communicative medium: Weblog. ESP-World, 4(3). [Online] Available: http://eflt.nus.edu.sg/v6sp12009/ho.htm\#Arani\%202005

Bernstein, M. (2004). Do blogs improve writing? [Online] Available: http://markbernstein.org/Jan0401.html\#note_35302 (August, 2010)

Blackstone, B. Spiri, J., \& Naganuma, N. (2007). Blogs in English Language Teaching and Learning: Pedagogical Uses and Student Responses. Reflections on English Language Teaching, 6(2), 1-20. [Online] Available: http://www.nus.edu.sg/celc/publications/RETL62/01to20blackstone.pdf

Bloch, J. (2004). Second language cyber rhetoric: A study of Chinese L2 writers in an online Usenet group. Language Learning \& Technology, 8(3), 66-82. [Online] Available: http://lt.msu.edu/vol8num3/bloch/default.html

Campbell, A. (2003, March 18). Weblogs for use with ESL classes. The Internet TESL Journal, 9(2)

Cobanoglu, C. (2006). An Analysis of Blogs as a Teaching Tool as Perceived by Hospitality Management Students. Journal of Hospitality, Leisure, Sport and Tourism Education, Vol. 5, No. 2. ISSN: 1473-8376

Daud, N. S., Daud, N., \& Abu Kassim, N. L. (2005). Second language writing anxiety: Cause or effect? Malaysian Journal of ELT Research, Inaugural.

Davis, J. N. (1997). Computer and L2 reading: Student performance, student attitudes. Foreign Language Annals, 30(1), 58-72. http://dx.doi.org/10.1111/j.1944-9720.1997.tb01317.x

De Izquierdo, B. L., \& Reyes, L. E. (2009). Effectiveness of Blogging to Practice Reading at a Freshman EFL Program. The Reading Matrix, Volume 9, Number 2, September 2009

Dewitt, S. L. (1996). The current nature of hypertext research in computers and composition studies. Computers and Composition, 13(1), 69-84. http://dx.doi.org/10.1016/S8755-4615(96)90036-5

Dieu, B. (2004). Blogs for language learning. Essential Teacher, 26-30

Ding, Zhao-guo. (2008). Application of Blog to English Language Teaching in China. International Conference on Computer Science and Software Engineering.

Downs, S. (2004). Educational blogging. Educause Review, 39(5), 14-26

Eastment, D. (2005). Blogging. ELT Journal. 59 (4), 358-361. http://dx.doi.org/10.1093/elt/cci073

Efimova, L., \& Fiedler, S. (2003). Learning webs: Learning in weblog networks. In P. Kommers, P. Isaias, \& M. B. Nunes (Eds.), Proceedings of the IADIS International Conference Web Based Communities 2004. Lisbon: IADIS Press. pp. 490-494

Ellison, N., \& WU Y. (2008). Blogging in the classroom: A preliminary exploration of student attitudes and impact on comprehension. Journal of Educational Multimedia and Hypermedia, 17(1), 99-122

Galien, P., \& Bowcher, W. L. (2010). Using Blogs in ESL/EFL Teaching and Teacher-Training. Asian EFL Journal. Professional Teaching Articles. Vol. 42, February.

Hanson Smith, E. (2001). Computer-assisted language learning. In R. Carter, \& D. Nunan (Eds.), The Cambridge guide to teaching English to speakers of other languages. Cambridge, UK: Cambridge University Press. pp. 107-113. http://dx.doi.org/10.1017/CBO9780511667206.016

Ho, B., \& Richards, J. C. (1993). Reflective thinking through teacher journal writing: Myths and realities. Prospect, $8,7-24$

Ho, G. A. (2009). Blogging and Vietnamese Language Teaching and Learning. Electronic Journal of Foreign Language Teaching, Vol. 6, Suppl. 1, 268-277. Centre for Language Studies National University of Singapore.

Liaw, S. S., Chen, G. D., \& Huang, H. M. (2008). Users' attitudes toward Web-based collaborative learning systems 
for knowledge management. Computers and Education, 50(3), 950-961. http://dx.doi.org/10.1016/j.compedu.2006.09.007

Kavaliauskienè, G., \& Vaičiūnienè, V. (2006). Communication Interaction Using Information and Communication Technology. Studies About Languages (Kalbų Studijos), 8, 8894. [Online] Available: www.ceeol.com

Miranda Bella. Weblogs and Their Effects on Writing Skills. May 9, 2005

Nadzrah Abu Bakar, \& Kemboja Ismail. (2009). Using Blogs to Encourage ESL Students to write constructively in English. AJTLHE, 1/5, 45-57

National Education Technology Plan. (2004). Toward a new golden age in American education: How the Internet, the law and today's students are revolutionizing expectations. Washington, D.C.: U.S. Department of Education, Office of Educational Technology.

Perseus. (2005). The Blogging Geyser. [Online] Available: http://www.perseus.com/blogsurvey/geyser.html

Pinkman, Kathleen. (2005). Using Blogs in the Foreign Language Classroom; Encouraging Learner Independence. The JALT CALL Journal, 1/1, 12-24

Richardson, W. (2006). Blogs, wikis, podcasts, and other powerful Web tools for classrooms. Thousand Oaks, CA: Corwin Press.

Rodzvilla, J. (2002). We've got blog: How weblogs are changing our culture. Cambridge, MA: Perseus Publishing.

Ross, T. (2002). You web log, we web log: A guide to how educator librarians can use Web logs to build communication and research skills. Educator Librarian, 30(2), 7

Seitzinger, Joyce. (2006). Be Constructive: Blogs, Podcast, and Wikis as Constructivist learning Tools. Learning Solutions, 7

Simsek, O. (2009). The Effect of Weblog Intergated Writing Instruction on Primary School Students Writing Performance. International Journal of Instruction, July 2009, Vol.2, No.2, ISSN: 1694-609X. [Online] Available: www.e-iji.net

Song, H., \& Chan, Y. (2008). Educational blogging: A Malaysian university students' perception and experience. Proceedings ascilite Melbourne 2008. Full paper: Song \& Chan.

Stanley, G. Blogging for ELT. [Online] Available: http://www.teachingenglish.org.uk/think/resources/blogging.shtml (April 10, 2008)

Stiler, G. M., \& Philleo, T. (2003). Blogging and blogspots: An alternative format for encouraging reflective practice among preservice teachers. Academic Research Library, 123(4), 789-798

Sun, Y. (2009). Voice Blog: An Exploratory Study of Language Learning. Language Learning \& Technology, June, Volume 13, Number 2, 88-103

Tekinarslan, E. (2008). Blogs: A qualitative investigation into an instructor and undergraduate students' experiences. Australasian Journal of Educational Technology, 24(4), 402-412

Tseng, Min-Chen. (2008). The Use of Blogs in English Classes for Medicine-Related Majors. Chang Gung Journal of Humanities and Social Sciences, 1, 1168

Yih, M. B., \& Nah, E. A. (2009). Writing Web Logs in the ESL Classroom: A Study of Student Perceptions and the Technology Acceptance Model 47. Asian Journal of University Education, Vol.5, No.1, June, ISSN 1823-7797

Walker, J. (2005). Weblogs: Learning in Public. On the Horizon, 13(2). http://dx.doi.org/10.1108/10748120510608142

Warschauer, M. (2010). Invited Commentary: New Tools For Teaching Writing. Language Learning \& Technology, February, Volume 14, Number 1

Ward, J. M. (2004). Blog assisted language learning. Push button publishing for the pupil. TEFL Web Journal, 3, 1

Williams, J. B., \& Jacobs, J. (2004). Exploring the use of blogs as learning spaces in the higher education sector. Australasian Journal of Educational Technology, 20(2), 232-247

Witte, S. (2007). That's online writing, not boring school writing: Writing with blogs and the Talkback Project. Journal of Adolescent \& Adult Literacy, 51, 2, October. http://dx.doi.org/10.1598/JAAL.51.2.1

Zhang, D. (2009). The Application of Blog in English Writing. Journal of Cambridge Studies, Vol. 4, No. 1, March. 
Table 1. Learner Blog

\begin{tabular}{|c|c|c|c|c|c|}
\hline No & statements (Learner Blog) & A & & $\mathrm{D}$ & \\
\hline 1 & I am glad that I have my own English blog. & 34 & 97.1 & 1 & 2.9 \\
\hline 2 & I feel it is quite easy to create and publish my own blog. & 32 & 91.4 & 3 & 8.6 \\
\hline 3 & I think I have no difficulty in using my blog. & 32 & 90 & 3 & 10 \\
\hline 4 & I feel comfortable using the blog. & 29 & 82.9 & 6 & 17.1 \\
\hline 5 & Writing on weblog was enjoyable and interesting. & 31 & 88.6 & 4 & 11.4 \\
\hline 6 & I think the learner blog is a waste of time. & 7 & 20 & 28 & 80 \\
\hline 7 & It is fast and convenient to update information on the blogs. & 31 & 88.6 & 4 & 11.4 \\
\hline 8 & I like posting many articles and photos or clips of films on the blog. & 25 & 71.4 & 10 & 28.6 \\
\hline 9 & I like to invite my classmates to read my blogs. & 27 & 77.1 & 8 & 22.9 \\
\hline 10 & $\begin{array}{l}\text { Reading the comments and entries of my peers on the blog helped } \\
\text { me to learn and improve my own writing. }\end{array}$ & 26 & 74.3 & 9 & 25.1 \\
\hline 11 & I like making comments on my classmates' posts. & 24 & 68.6 & 11 & 31.4 \\
\hline 12 & $\begin{array}{l}\text { Responding to the comments received on my blog improves my } \\
\text { writing. }\end{array}$ & 28 & 80 & 7 & 20 \\
\hline 13 & I found it difficult to comment on the blogs of my peers. & 25 & 71.4 & 10 & 28.6 \\
\hline 14 & I like having classmates make comments on my posts. & 30 & 85.7 & 5 & 14.3 \\
\hline 15 & $\begin{array}{l}\text { I don't have to worry of what my friends would think of my } \\
\text { language when I blog in English. }\end{array}$ & 28 & 80 & 7 & 20 \\
\hline 16 & I like reading my classmates' written posts. & 32 & 91.4 & 3 & 8.6 \\
\hline 17 & I feel uncomfortable about my peers' comments. & 21 & 60 & 14 & 40 \\
\hline 18 & I like having my instructor make written comments on my post. & 35 & 100 & 0 & 0 \\
\hline 19 & $\begin{array}{l}\text { I feel that blog is a useful tool for me to share ideas with others } \\
\text { online. }\end{array}$ & 30 & 85.7 & 5 & 14.3 \\
\hline 20 & I prefer to practice my writing in the blog rather than in the class. & 25 & 71.4 & 10 & 28.6 \\
\hline 21 & $\begin{array}{l}\text { I feel that my writing is better when writing on my blogs than } \\
\text { writing on paper in class. }\end{array}$ & 30 & 85.7 & 5 & 14.3 \\
\hline 22 & I can be more creative when writing on my blogs than on paper. & 25 & 71.4 & 10 & 28.6 \\
\hline 23 & I could get help when I wrote on the blog like in the class. & 26 & 74.3 & 9 & 25.7 \\
\hline 24 & $\begin{array}{l}\text { I feel no pressure when writing on my blog because I have more } \\
\text { time to write. }\end{array}$ & 27 & 77.1 & 8 & 22.9 \\
\hline 25 & I feel more confident with writing on my blog than on paper. & 21 & 60 & 14 & 40 \\
\hline 26 & $\begin{array}{l}\text { I can express my idea better when writing on my blog than on } \\
\text { paper. }\end{array}$ & 32 & 91.4 & 3 & 8.6 \\
\hline 27 & I feel free to write on the blog than in the class. & 24 & 68.6 & 11 & 31.4 \\
\hline
\end{tabular}




\begin{tabular}{|c|c|c|c|c|c|}
\hline 28 & $\begin{array}{l}\text { I feel that I can write longer when writing on my blog than on } \\
\text { paper. }\end{array}$ & 24 & 68.6 & 11 & 31.4 \\
\hline 29 & $\begin{array}{l}1 \text { prefer the blogging way of submitting my assignments to the } \\
\text { traditional way of submitting assignments. }\end{array}$ & 32 & 91.4 & 3 & 8.6 \\
\hline 30 & $\begin{array}{l}\text { I am motivated to write my opinion on the blog when I agree or } \\
\text { disagree with peers' comments. }\end{array}$ & 32 & 91.4 & 3 & 8.6 \\
\hline 31 & I have improved my writing skills since I began blogging & 29 & 82.9 & 6 & 17.1 \\
\hline 32 & $\begin{array}{l}\text { In general I feel that my English grammar has somewhat improved } \\
\text { since I began blogging. }\end{array}$ & 28 & 80 & 7 & 20 \\
\hline 33 & $\begin{array}{l}\text { I can use the different word forms in English (i.e. tenses: eat, ate, } \\
\text { eaten). }\end{array}$ & 27 & 77.1 & 8 & 22.9 \\
\hline 34 & I learn more new words when reading my friends' postings. & 32 & 91.4 & 2 & 8.6 \\
\hline 35 & $\begin{array}{l}\text { I am more active in checking up meaning of difficult words in the } \\
\text { dictionary when blogging. }\end{array}$ & 21 & 60 & 14 & 40 \\
\hline 36 & Having my own blog encourages me to write better & 26 & 74.3 & 9 & 25.7 \\
\hline 37 & $\begin{array}{l}\text { I think content writing for blogs contributed to my writing skills } \\
\text { related to organization, paraphrasing, referencing etc. }\end{array}$ & 27 & 77.1 & 8 & 22.9 \\
\hline 38 & Using writing blog can increase my productivity. & 23 & 65.7 & 12 & 34.3 \\
\hline 39 & $\begin{array}{l}\text { I think it is a good idea to use blogs to practice writing skills in } \\
\text { English. }\end{array}$ & 35 & 100 & 0 & 0 \\
\hline 40 & I am more careful with my writing when blogging. & 21 & 60 & 14 & 40 \\
\hline 41 & I always check my sentences before I post my writing on the blogs. & 22 & 62.9 & 13 & 27.1 \\
\hline 42 & I don't like to check my writing when I write on paper. & 14 & 40 & 21 & 60 \\
\hline 43 & $\begin{array}{l}\text { I like to write a draft of what I wanted to say before I submitted the } \\
\text { blog response. }\end{array}$ & 29 & 82.6 & 6 & 17.4 \\
\hline 44 & When I write on the blog, I don't worry about mistakes. & 31 & 88.7 & 4 & 11.3 \\
\hline 45 & I enjoy the blog project. & 34 & 97.1 & 1 & 2.9 \\
\hline 46 & $\begin{array}{l}\text { Without an English or composition class, I will still use my blog in } \\
\text { the future. }\end{array}$ & 29 & 82.9 & 6 & 17.1 \\
\hline
\end{tabular}

Table 2. Learner-perceived advantages

\begin{tabular}{|l|l|}
\hline Response & $\begin{array}{l}\text { (Total No. of } \\
\text { Students =35) }\end{array}$ \\
\hline 1.Blog gives participants opportunities to practice writing & 20 \\
\hline 2.free writing & 18 \\
\hline $\begin{array}{l}\text { 3. Blog provides the avenue for students who are uncomfortable to voice } \\
\text { their opinion in person. }\end{array}$ & 17 \\
\hline 4. Blog is helpful in learning and using new vocabulary. & 16 \\
\hline 5. Blog is easy to use & 15 \\
\hline 6. Blog is very cheap and convenient. & 13 \\
\hline
\end{tabular}


Table 3. Learner-perceived disadvantages

\begin{tabular}{|l|l|}
\hline Response & $\begin{array}{l}\text { Total No. of } \\
\text { Students =35) }\end{array}$ \\
\hline 1. lack of feedbacks and corrections & 21 \\
\hline $\begin{array}{l}\text { 2. The assignment was too time-consuming and/or should have been } \\
\text { done in-class }\end{array}$ & 19 \\
\hline 3. the problem of logging in and other technical difficulties. & 16 \\
\hline $\begin{array}{l}\text { 4. some teacher blogs lack regular updating and fail to respond to } \\
\text { learners' questions without delay }\end{array}$ & 15 \\
\hline 5. lacking traditional format & 12 \\
\hline 6. Lack of participation and physical contact with students & 10 \\
\hline 7 Negative comments & 10 \\
\hline
\end{tabular}

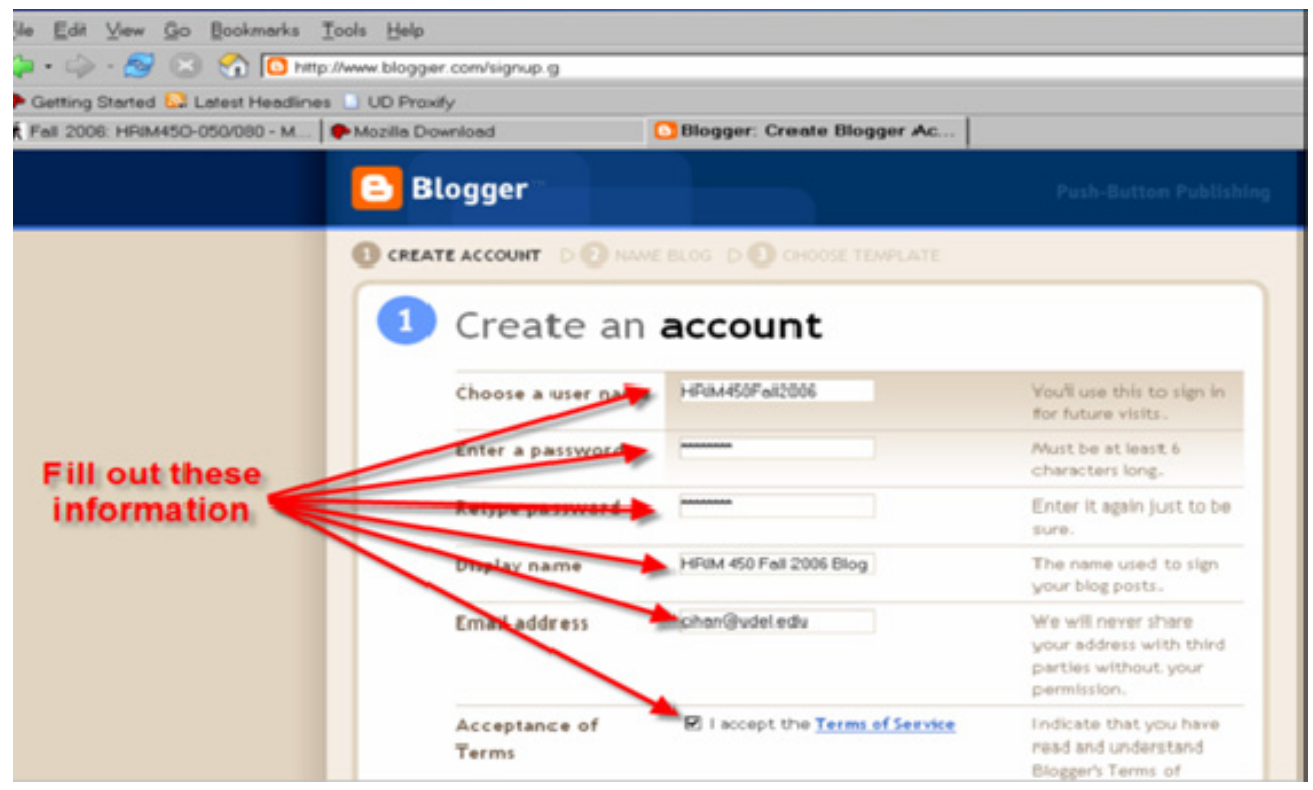

Figure 1. Creating an account on blogger 